\title{
Clinical and hematological prognostic factors in dogs with parvoviral enteritis and sepsis
}

\section{Fatores prognósticos clínicos e hematológicos em cães com enterite por Parvovírus e sepse}

\author{
Fernanda dos Santos Alves ${ }^{*}$; Breno Curty Barbosa ${ }^{2}$; Nathália das Graças Dorneles \\ Coelho $^{2}$; Paula Costa de Oliveira Pinto $^{2}$; Marco Túlio Gomes Campos²; Rodrigo \\ dos Santos Horta ${ }^{3}$; Patrícia Maria Coletto Freitas ${ }^{4}$; Suzane Lilian Beier ${ }^{4}$; Paulo \\ Ricardo de Oliveira Paes ${ }^{4}$
}

\begin{abstract}
Parvoviral enteritis is a common viral infection in dogs and is associated with many clinical and hematological changes. Bacterial translocation is a common complication and may result in sepsis. The objective of this study is to determine the presence of clinical and hematological factors associated with the risk of death in puppies with naturally occurring parvoviral enteritis and sepsis. Twenty-four dogs with parvoviral enteritis confirmed by chromatographic immunoassay during the clinical routine of a university veterinary hospital were selected. At admission and every 24 hours until the third day of hospitalization or until death, venous blood samples were collected for complete blood count, renal and hepatic biochemistry, and lactate and magnesium measurement; arterial blood samples were collected for gas analysis. Sodium, potassium, and ionized calcium were also analyzed, and a complete physical examination was performed. The factors associated with mortality were evaluated by Cox univariate analysis at a level of significance of $5 \%$. The increase in urea and heart rate was associated with an increase in the risk of death. In contrast, an increase in total leukocytes, lymphocytes, monocytes, partial pressure of oxygen, base deficit, bicarbonate ion, and oxygen saturation were associated with a reduction in the risk of death.
\end{abstract}

Key words: Risk factors. Mortality. Clinical pathology. Canine parvovirus.

\section{Resumo}

A enterite por Parvovírus é uma infecção viral comum em cães e é associada a diversas alterações clínicas e hematológicas. A translocação bacteriana é uma complicação comum e pode resultar em sepse. O objetivo do estudo foi determinar a presença de fatores clínicos e hematológicos associados ao risco de óbito em filhotes com parvovirose de ocorrência natural e sepse. Vinte e quatro cães com parvovirose, confirmada através de imunoensaio cromatográfico, foram selecionados a partir da rotina clínica do Hospital Veterinário. À admissão e a cada 24 horas até o terceiro dia de hospitalização ou até óbito, amostras de sangue venoso foram coletadas para realização de hemograma, bioquímica renal e hepática, mensuração de lactato e magnésio; amostras de sangue arterial foram coletadas para gasometria. Foram

1 Pesquisadora, Universidade Federal de Minas Gerais, UFMG, Belo Horizonte, MG, Brasil. E-mail: fsalves.vet@gmail.com

2 Discentes, Programa de Pós-Graduação em Ciência Animal, UFMG, Belo Horizonte, Brasil. E-mail: brenocurty@hotmail.com; natvetufmgtablet@gmail.com; paulacosta10@hotmail.com; camposmtg@gmail.com

3 Prof., Universidade de Vila Velha, UVV, Vila Velha, ES, Brasil. E-mail: rodrigohvet@gmail.com

4 Profs., UFMG, Belo Horizonte, MG, Brasil.E-mail: pcoletto@yahoo.com.br; suzanelb@yahoo.com.br; paulopaes@vet.ufmg.br Author for correspondence 
analisados também sódio, potássio e cálcio ionizado, bem como foi realizado o exame físico completo. Os fatores associados à mortalidade foram avaliados através de análise univariada de Cox com um nível de significância de 5\%. O aumento da concentração de ureia e da frequência cardíaca foram associados à elevação do risco de óbito. Em contraste, o aumento nos valores de leucócitos totais, linfócitos, monócitos, pressão parcial de oxigênio, déficit de base, íon bicarbonato e saturação de oxigênio foram associados à redução do risco de óbito.

Palavras-chave: Fatores de risco. Mortalidade. Patologia clínica. Parvovirose canina.

\section{Introduction}

Dogs younger than one year are frequently diagnosed with gastrointestinal infections and, among them, parvoviral enteritis remains a significant cause of morbidity and mortality in this population (GODDARD; LEISEWITZ, 2010). The virus spreads from one animal to another via oronasal exposure to contaminated feces and has tropism to lymphoid tissue, bone marrow, and the intestinal epithelium. This virus can also infect the myocardium of dogs younger than three weeks (PRITTIE, 2004), although some authors reported that myocarditis occurred exclusively in puppies infected during gestation or soon after birth (MIRANDA et al., 2015). The clinical manifestations depend on the affected cell types. Immunosuppression can be caused by the death of myeloproliferative cells and thymic lymphocytolysis. Damage to the intestinal mucosa and villous atrophy cause malabsorption, diarrhea, and vomiting, and this condition can rapidly progress to shock and death as a result of dehydration, severe protein loss, bacterial sepsis, and endotoxemia (GODDARD; LEISEWITZ, 2010). The mortality rate of this disease can reach $91 \%$ in dogs without treatment, although the rate is $5-15 \%$ in animals subjected to aggressive and immediate treatment (PRITTIE, 2004).

Many risk factors are associated with parvoviral enteritis, including the absence of protective immunity, low-hygiene environments, endoparasites, and age (PRITTIE, 2004). The clinical signs are initially unspecific and include vomiting, anorexia, depression, fever, small bowel diarrhea, and abdominal pain (PRITTIE,
2004; LAMM; REZABEK, 2008)environmental resistance, high dose of viral shedding, and interspecies transmission have made some strains of parvovirus infection difficult to control within domestic animal populations. Some parvoviruses in companion animals, such as canine parvovirus (CPV. Furthermore, signs of hypoperfusion, including the reduction in the capillary refill time, oliguria, changes in mental state, and laboratory abnormalities such as hyperlactatemia may be present, and hypovolemic and/or septic shock may occur in severe cases (PRITTIE, 2004).

The leukocyte count is usually reduced, and lymphopenia is the most consistent finding in dogs with parvovirus infection. Such alterations may be caused by the destruction of hematopoietic progenitor cells in the bone marrow and other lymphoproliferative organs. Anemia is another common finding in hematological examinations and may be the result of either intestinal bleeding or dilution caused by fluid therapy. The biochemical abnormalities are unspecific, and the most common abnormalities are hypokalemia and hypoalbuminemia due to enteric loss or anorexia, azotemia of pre-renal origin associated with dehydration, and an increase in alkaline phosphatase and alanine aminotransferase due to severe dehydration and low tissue perfusion and resulting in damage to hepatocytes (PRITTIE, 2004; GODDARD; LEISEWITZ, 2010).

The current definition of sepsis in veterinary medicine is similar to that used in human medicine, characterized by a systemic inflammatory response to infection (SRIS). The clinical diagnosis of 
SRIS is based on abnormalities in the heart and respiratory rate, rectal temperature, and leukocyte count (SHARP, 2019).

The purpose of this study is to define the prognostic value of complete blood count, arterial blood gas analysis parameters, electrolytes, and clinical signs in puppies naturally infected with parvovirus.

\section{Material and Methods}

From June 2014 to January 2016, 36 dogs with parvoviral enteritis were assisted at the Veterinary Teaching Hospital of the Veterinary School of the Federal University of Minas Gerais (Universidade Federal de Minas Gerais-UFMG). Of these, 24 dogs were selected after the consent and clarification of the owners, and the other animals were not included because of the non-consent of the owners or financial restrictions. The research was approved by the Animal Research Ethics Committee of UFMG (Protocol No. 259/2015), and the animals were included in the study only after the consent of the owners.

The inclusion criteria were the presence of clinical signs of parvovirus infection (anorexia, vomiting, lethargy, and hemorrhagic enteritis) of acute onset (less than 3 days) without treatment, a positive result in the chromatographic immunoassay of fecal sample (BioEasy ${ }^{\circledR}$ - Alere Parvovirose Ag, Belo Horizonte, Brazil), animals younger than one year of age, and animals classified as septic. The definition of sepsis used in this research was the presence of SRIS and the identification of concurrent infection. For the diagnose of sepsis, the study animal had to fulfill two of the following SIRS criteria: abnormal temperature $\left(>39^{\circ} \mathrm{C}\right.$ or $\left.<38^{\circ} \mathrm{C}\right)$, abnormal heart rate ( $>120$ beats/minute), abnormal respiratory rate $(>20$ breaths $/ \mathrm{min}$ ), and changes in white blood cell count $(<6,000$ or $>16,000$ cells/ $\left.\mu \mathrm{L}^{-1}\right)$ together with the diagnosis of infection. The SRIS criteria used in this study were defined by
Hauptman et al. (1997).

The animals were admitted to the hospital kennel for infectious diseases and were treated with amoxicillin and clavulanic acid (Doclaxin; Blau pharmaceutical services) at $22 \mathrm{mg} \mathrm{kg}^{-1}$ every 12 hours intravenously (IV); metronidazole (Flagyl; Sanofi Aventis) at $15 \mathrm{mg} \mathrm{kg}^{-1}$ every 12 hours IV, maropitant (Cerenia; Zoetis) at $1 \mathrm{mg} \mathrm{kg}^{-1}$ every 24 hours, dipyrone (Dipirona Teuto; Teuto) at $25 \mathrm{mg} \mathrm{kg}^{-1}$ every 8 hours, and fluid therapy with balanced isotonic solution (lactated Ringer's solution; Eurofarma Laboratories) supplemented with potassium and/or glucose as needed). For fluid therapy, the estimated percentage dehydration was infused in each animal within the first 4 hours of hospitalization. In the remaining 20 hours, the calculation of the maintenance dose was based on the initial rate of $60 \mathrm{ml} \mathrm{kg}^{-1} \mathrm{day}^{-1}$, and the losses due to vomiting or diarrhea were estimated and added to the final total. The rate of fluid therapy was reevaluated every 12 hours for volume suitability. In view of the presence of hypoalbuminemia in the study animals, the total volume of replacement fluid and the rate of replacement were constantly reevaluated to detect fluid overload. The signs of fluid overload are peripheral edema, chemosis, serous nasal secretion, and acute pulmonary edema.

At hospital admission and during hospitalization until discharge or death, the dogs were subjected to physical examination every 12 hours (assessment of the mental state, mucosal color and moisture, body temperature, heart and respiratory rate, cardiopulmonary and abdominal auscultation, palpation, pulse quality, and systolic blood pressure), determination of fecal consistency and blood collection through the external jugular vein for blood count (in a test tube containing anticoagulant EDTA), serum biochemistry (in a test tube without coagulant), and evaluation of glycemia (in a test tube containing fluoride) every 24 hours. In addition, arterial blood was collected from the metatarsal artery every 24 hours for gas 
analysis. The blood count and biochemical tests were performed immediately upon arrival of the samples at the Laboratory of Clinical Pathology of the Veterinary School of UFMG. The serum was separated by centrifugation, aliquoted, frozen at -15 ${ }^{\circ} \mathrm{C}$, and analyzed within 15 days. Blood count was performed using an automatic cell counter (Abacus Junior; Diatron Messtechnik), and the differential count of leucocytes was performed by a veterinarian under an optical microscope. Biochemical tests (amylase, creatinine, urea, alanine aminotransferase (ALT), aspartate aminotransferase (AST), total protein, albumin, globulin, glucose, magnesium, and lactate) were performed using an enzymatic colorimetric method with commercial kits (Kovalent; São Gonçalo, Rio de Janeiro, Brazil), and absorbance was read in a spectrophotometer (Cobas Mira Plus; Roche Diagnostics). Arterial blood gas was analyzed using an i-STAT CG8+ cartridge and an i-STAT portable device (Heska Corporation, United States). The following parameters were measured: $\mathrm{pH}$, bicarbonate $\left(\mathrm{HCO}_{3}^{-}\right)$, partial pressure of carbon dioxide $\left(\mathrm{PaCO}_{2}\right)$, partial pressure of oxygen $\left(\mathrm{PaO}_{2}\right)$, arterial oxygen saturation $\left(\mathrm{SO}_{2}\right)$, sodium $(\mathrm{Na})$, potassium $(\mathrm{K})$, ionized calcium (iCa), and base deficit (BD).

The duration of the clinical assessment was 3 days. After this period, the surviving animals were discharged or continued to receive inhospital treatment as necessary. The discharged animals continued the oral treatment with the drugs prescribed during hospitalization until the return visit (in 48 hours), and nutritional support (a/d Urgent Care; Hill's Prescription Diet ${ }^{\mathrm{TM}}$, Brazil) was provided by the owner.

The risk factors for death were determined using Cox regression analysis. Statistical analyses were performed using the $\mathrm{R}$ software version 3.2.4. Differences with $\mathrm{p}<0.05$ were considered significant.

\section{Results and Discussion}

Parvoviral enteritis usually affects puppies aged 6 weeks to 6 months (PRITTIE, 2004). The mean age of the study sample was $3.9 \pm 2.4$ months. The occurrence of this disease at this age may be due to the interference of maternal antibodies in the immune response induced by vaccination (PRITTIE, 2004) or an inadequate, incomplete, or nonexistent vaccine protocol.

The survival rate in our sample was $83.3 \%$. Four deaths occurred during the 3 days of hospitalization and treatment (one death in the first day, one death in the third day, and two deaths in the second day), and no deaths occurred after the animals were discharged. It is known that the survival rate is as low as $9.1 \%$ in the absence of treatment and $\geq 64 \%$ with proper treatment (OTTO et al., 1997). The survival rate with aggressive therapy during hospitalization is $80-95 \%$ (PRITTIE, 2004), as confirmed in the present study.

Parvoviral enteritis was diagnosed by chromatographic immunoassay. The comparison of different methods of diagnosis of canine parvovirus infection indicated that the most sensitive tests in detecting the virus were polymerase chain reaction (PCR) (62.29\%), hemagglutination (HA) test $(50.81 \%)$, virus isolation in cell culture $(50.00 \%)$, chromatographic immunoassay $(37.70 \%)$, and sandwich enzyme-linked immunosorbent assay (ELISA) (31.14\%) (PANDYA et al., 2017). The comparison of the specificity of chromatographic immunoassay, PCR, and electron microscopy demonstrated that the specificity of the immunoassay was higher than $95 \%$ when compared to the other tests (SCHMITZ et al., 2009). However, the possibility of false-positive results cannot be ruled out because chromatographic immunoassay was the only test performed, and other causes of hemorrhagic gastroenteritis should be considered, including idiopathic acute hemorrhagic diarrhea syndrome, severe acute pancreatitis, intestinal 
foreign body, and infections with other virus or enteropathogenic bacteria (MORTIER et al., 2015).

In the present study, the diagnosis of sepsis in the animals that met the inclusion criteria defined by Hauptman et al. (1997) was based on the presence of infection and the criteria established in the 2001 consensus conference (LEVY et al., 2003). Of note, a new consensus (Sepsis-3) was recently introduced in human medicine to remove the excessive focus on inflammation as the pathological process in sepsis, among other reasons. Sepsis is defined by Sepsis-3 as a life-threatening organ dysfunction caused by a dysregulated host response to infection, and organ dysfunction is considered any acute change in total Sequential Organ Failure Assessment score $\geq 2$ points as a result of infection (SINGER et al., 2016). It is likely that the current veterinary definitions will be ultimately reconsidered because there is no consensus in veterinary medicine (SHARP, 2019); however, other authors do not know whether Sepsis-3 applies to veterinary medicine (LETENDRE; GOGGS, 2018). Therefore, the criteria chosen in this study was defined by Hauptman et al. (1997) and is still used by researchers for defining sepsis in dogs (WALTERS et al., 2017; HARDY et al., 2018; LETENDRE; GOGGS, 2018; SILVEIRA et al., 2018).

Among the physical parameters, only heart rate and systolic blood pressure were significant risk factors for death. The risk of death increased by $7 \%$ $(\mathrm{p}=0.006)$ and decreased by $8 \%(\mathrm{p}=0.002)$ with the increase in heart rate and a $1-\mathrm{mmHg}$ increase in SBP, respectively (Table 1). Rectal temperature and respiratory rate did not affect prognosis in our sample. In contrast, the increase in heart rate was associated with an increased risk of death, and this result may be related to the hemodynamic response in an attempt to maintain tissue perfusion. Hypotension is a cardiovascular dysfunction found in multiple organ dysfunction syndrome and is associated with poor prognosis. Hypotension may contribute to cardiovascular dysfunction in other organs (OSTERBUR et al., 2014). It is known that low systolic blood pressure $(<120 \mathrm{mmHg})$ has several effects on the body and requires early and aggressive treatment (HOLLENBERG, 2011). The initial goal of volemic resuscitation should be to restore blood pressure and improve cell metabolism (VINCENT; BACKER, 2013). Although traditional resuscitation goals (heart rate and blood pressure) may be insufficient to detect ongoing tissue hypoxia, such parameters should not be neglected, and normalization should be attempted. The optimization of early resuscitation improves survival in humans presented with shock (PRITTIE, 2006). In this study, the normalization of blood pressure and heart rate in dogs with parvoviral enteritis reduced the risk of death. 
Table 1. Cox univariate regressions for the occurrence of death in 24 dogs with parvoviral enteritis and sepsis.

\begin{tabular}{|c|c|c|c|c|}
\hline Variable & & $\mathbf{R R}^{*}$ & $95 \% \mathrm{CI}^{1}$ & p-value \\
\hline \multirow{4}{*}{ Physical parameters } & Rectal temperature & 4.38 & {$[0.78 ; 24.66]$} & 0.094 \\
\hline & Respiratory rate & 1.04 & {$[0.94 ; 1.15]$} & 0.450 \\
\hline & Heart rate & 1.07 & {$[1.02 ; 1.12]$} & 0.006 \\
\hline & Systolic blood pressure 3 ica $^{3}(\mathrm{mmHg})$ & 0.92 & {$[0.87 ; 0.97]$} & 0.002 \\
\hline \multirow{10}{*}{ Blood count } & Hemoglobin globular volume (\%) & 1.02 & {$[0.89 ; 1.17]$} & 0.782 \\
\hline & Hemoglobin $\left(\mathrm{g} \mathrm{dL}^{-1}\right)$ & 1.08 & {$[0.77 ; 1.52]$} & 0.651 \\
\hline & Blood cells $\left(10 / 6\right.$ cells $\left.\mu \mathrm{L}^{-1}\right)$ & 1.15 & {$[0.45 ; 2.98]$} & 0.767 \\
\hline & Total leukocytes (cells $\mu \mathrm{L}^{-1}$ ) & 0.83 & {$[0.72 ; 0.97]$} & 0.018 \\
\hline & Band neutrophils (cells $\mu \mathrm{L}^{-1}$ ) & 0.98 & {$[0.96 ; 1.01]$} & 0.152 \\
\hline & Segmented neutrophils (cells $\mu \mathrm{L}^{-1}$ ) & 0.99 & {$[0.98 ; 1.00]$} & 0.084 \\
\hline & Eosinophils (cells $\mu \mathrm{L}^{-1}$ ) & 0.99 & {$[0.97 ; 1.01]$} & 0.298 \\
\hline & Lymphocytes (cells $\mu \mathrm{L}^{-1}$ ) & 0.96 & {$[0.92 ; 0.99]$} & 0.013 \\
\hline & Monocytes (cells $\mu \mathrm{L}^{-1}$ ) & 0.98 & {$[0.97 ; 1.00]$} & 0.044 \\
\hline & Platelets (cells $\mu \mathrm{L}^{-1}$ ) & 1.00 & {$[1.00 ; 1.00]$} & 0.739 \\
\hline \multirow{10}{*}{ Serum biochemystry } & $\operatorname{ALT}^{4}\left(\mathrm{UI} \mathrm{L}^{-1}\right)$ & 1.00 & {$[0.98 ; 1.01]$} & 0.540 \\
\hline & Amilase (UI L-1) & 1.00 & {$[1.00 ; 1.00]$} & 0.208 \\
\hline & $\mathrm{AST}^{4}\left(\mathrm{UI} \mathrm{L}^{-1}\right)$ & 1.00 & {$[0.99 ; 1.01]$} & 0.779 \\
\hline & Creatinine $\left(\mathrm{mg} \mathrm{dL}^{-1}\right)$ & 2.58 & {$[0.09 ; 71.04]$} & 0.575 \\
\hline & Total protein $\left(\mathrm{mg} \mathrm{dL}^{-1}\right)$ & 0.72 & {$[0.23 ; 2.28]$} & 0.582 \\
\hline & Albumin $\left(\mathrm{g} \mathrm{dL}^{-1}\right)$ & 0.31 & {$[0.05 ; 1.98]$} & 0.216 \\
\hline & Globulins $\left(\mathrm{g} \mathrm{dL}^{-1}\right)$ & 1.29 & {$[0.22 ; 7.67]$} & 0.777 \\
\hline & Urea $\left(\mathrm{mg} \mathrm{dL}^{-1}\right)$ & 1.03 & {$[1.01 ; 1.05]$} & 0.008 \\
\hline & Lactate $\left(\mathrm{mg} \mathrm{dL}^{-1}\right)$ & 1.00 & {$[0.94 ; 1.07]$} & 0.998 \\
\hline & Magnesium $\left(\mathrm{mg} \mathrm{dL}^{-1}\right)$ & 3.15 & {$[0.68 ; 14.62]$} & 0.143 \\
\hline \multirow{10}{*}{ Arterial blood gas } & $\mathrm{pH}$ & 0.62 & {$[0.00 ; 30438.62]$} & 0.932 \\
\hline & $\mathrm{PaCO}_{2}^{4}(\mathrm{mmHg})$ & 0.83 & {$[0.61 ; 1.14]$} & 0.258 \\
\hline & $\mathrm{PaO}_{2}^{4}(\mathrm{mmHg})$ & 0.90 & {$[0.82 ; 0.99]$} & 0.025 \\
\hline & $B E^{4}\left(\mathrm{mmol} \mathrm{L}^{-1}\right)$ & 0.62 & {$[0.42 ; 0.92]$} & 0.018 \\
\hline & $\left.\mathrm{HCO}_{3}^{-}(\mathrm{mmol} \mathrm{L})^{-1}\right)$ & 0.57 & {$[0.33 ; 0.97]$} & 0.039 \\
\hline & $\mathrm{SO}_{2}^{4}(\%)$ & 0.89 & {$[0.80 ; 0.99]$} & 0.039 \\
\hline & Sodium $\left(\mathrm{mEq} \mathrm{L}^{-1}\right)$ & 0.97 & {$[0.81 ; 1.16]$} & 0.747 \\
\hline & Potassium $\left(\mathrm{mEq} \mathrm{L}^{-1}\right)$ & 1.67 & {$[0.09 ; 30.5]$} & 0.729 \\
\hline & Ionized calcium $\left(\mathrm{mmol} \mathrm{L}^{-1}\right)$ & 0.42 & {$[0.00 ; 41.87]$} & 0.710 \\
\hline & Glucose $\left(\mathrm{mg} \mathrm{dL}^{-1}\right)$ & 1.03 & {$[1.00 ; 1.05]$} & 0.059 \\
\hline
\end{tabular}

*RR, relative risk; 95\% CI, 95\% confidence interval.

The variables in bold were associated with an increase in the risk of death.

The variables in italics had their increase associated with a reduction in the risk of death.

ALT, alanine aminotransferase; $\mathrm{AST}$, aspartate aminotransferase; $\mathrm{PaCO}_{2}$, partial pressure of carbon dioxide; $\mathrm{PaO}_{2}$, partial pressure of oxygen; $\mathrm{BE}$, base excess; $\mathrm{HCO}_{3}^{-}$, bicarbonate ion; $\mathrm{SO}_{2}$, oxygen saturation. 
Since leukocyte count and morphology are normal in healthy individuals, leukocyte responses may be useful in clinical routine because of the changes that may occur during the course of a disease. Leukocyte changes can provide clinical information that contributes to differential diagnosis, follow-up of the response to treatment, and prognosis (GODDARD et al., 2008). Total leukocytes and the differential count of lymphocytes and monocytes affected the risk of death in our sample. The risk was reduced by $17 \%$ with an increase of 100 leukocytes $\mu \mathrm{L}^{-1}$ (p $=0.018)$, by $4 \%$ with an increase of 10 lymphocytes $\mu \mathrm{L}^{-1}(\mathrm{p}=0.013)$, and by $2 \%$ with an increase of one monocyte $\mu \mathrm{L}^{-1}(\mathrm{p}=0.044)$ (Table 1$)$.

In the study sample, the increase in total leukocyte count was associated with a decrease in the risk of death. Goddard et al. (2008) observed that the number of white blood cells increased in surviving dogs at 24 hours after hospital admission and beginning of treatment. Nonetheless, the mean number of leukocytes in non-surviving dogs remained below the lower limits of normality. Lymphopenia is an expected early finding in acute and severe diseases. The return to normal values indicates good prognosis. In parvoviral enteritis and other viral diseases, the virus causes direct damage to the lymphoid tissue, and the cells of this tissue are redistributed because of stress or exposure to antigens (RASKIN et al., 2004). In such situations, transient lymphopenia is the most characteristic finding in differential leukocyte counts (GODDARD; LEISEWITZ, 2010). Drewry et al. (2014) have found that determining the time at which persistent lymphopenia becomes clinically relevant is difficult. There may be categories of patients in whom lymphocytic patterns may diverge between survivors and non-survivors. For instance, persistent lymphopenia in septic patients indicates the need to re-evaluate the response to therapy, and its presence on the fourth day in this patient subgroup can predict early and late mortality (DREWRY et al., 2014). In the present study, the increase in the number of lymphocytes (in 10 cells $\mu \mathrm{L}^{-1}$ ) reduced the risk of death by 4\%. Goddard et al. (2008) reported that puppies with a significant increase in the number of lymphocytes after 24 hours of admission had a better prognosis than animals that did not survive. The change in this parameter over time from admission was significantly different between surviving and non-surviving patients. The authors concluded that the absence of cytopenia, specifically leucopenia and lymphopenia, had a positive predictive value of $100 \%$ for survival in the first 24 hours after hospitalization. Another study demonstrated that lymphopenia increased hospitalization time in this category of patients (KALLI et al., 2010). The increase in monocyte count (in $\geq 1$ cell $\mu \mathrm{L}^{-1}$ ) also reduced the risk of death. As also observed in the present study, Goddard et al. (2008) found that the number of monocytes strongly affected prognosis in dogs, distinguishing between survivors and non-survivors. Monocytes are essential in this disease because they function as macrophages by removal of necrotic debris, viral inactivation, response to foreign bodies, and phagocytosis of senescent or abnormal erythrocytes (RASKIN et al., 2004).

The changes in clinical biochemistry are nonspecific in many viral diseases (GODDARD; LEISEWITZ, 2010). In this study, an increase in urea in $1 \mathrm{mg} \mathrm{dL}^{-1}$ increased the risk of death by $3 \%$. A study found that urea levels were higher in dogs with parvoviral enteritis that died compared to survivors. There was a positive correlation between urea concentrations and the death of dogs with parvovirus infection, and the authors concluded that acute renal injury occurred in the animals that died because urea and creatinine increased gradually until death (BASTAN et al., 2013). Among the biochemical parameters, ALT, AST, amylase, creatinine, total protein, albumin, globulin, glucose, lactate, and magnesium did not significantly affect prognosis $(\mathrm{p}<0.01)$.

Lactate had no influence on the risk of death in the study animals. Lactate is a marker of tissue hypoperfusion and hypoxia, and its decreased 
levels over the course of treatment suggest clinical improvement and may help predict outcomes (SHARKEY; WELLMAN, 2013). A recent study reviewed the human and veterinary literature on the utility of lactate as a prognostic indicator and a therapeutic guide, lactate measurement in body fluids other than plasma or blood, and the clinical management of lactate levels in different species. The authors concluded that lactate used as a therapeutic guide is relatively uninvestigated in dogs, cats, and horses, and that it is a valuable triage and risk stratification tool (ROSENSTEIN et al., 2018). The inability to reduce lactate levels by at least $50 \%$ at 6 hours was significantly associated with mortality in univariate analysis in hyperlactatemic dogs classified as critically ill according to the definition of the American Society of Anesthesiologists (STEVENSON et al., 2007). Another study demonstrated that a decrease in the initial lactate levels by $50 \%$ or more within 12 hours was a better survival indicator than its isolated value in dogs with gastric dilatation-volvulus (GREEN et al., 2011).

The results of gas and electrolytic analyses indicated that changes in $\mathrm{pH}, \mathrm{PaCO}_{2}$, sodium, potassium, and ionized calcium did not significantly affect prognosis. However, changes in $\mathrm{PaO}_{2}, \mathrm{BE}$, $\mathrm{HCO}_{3}^{-}$, and $\mathrm{SO}_{2}$ significantly affected prognosis. A 1-mmHg increase in $\mathrm{PaO}_{2}, \mathrm{BD}$, and $\mathrm{HCO}_{3}^{-}$reduced the risk of death by $10 \%(\mathrm{p}=0.025), 38 \%(\mathrm{p}=$ $0.018), 43 \%(\mathrm{p}=0.039)$, respectively, and a $1 \%$ increase in $\mathrm{SO}_{2}$ reduced the risk of death by $11 \%(\mathrm{p}$ $=0.039)($ Table 1$)$.

Metabolic acidosis is a common finding in dogs with parvovirus infection, probably because of excessive loss of bicarbonate through the intestinal tract (GODDARD; LEISEWITZ, 2010). However, in the present study, the proportion of animals with metabolic acidosis at admission was low, and the values were either normal or close to the minimum normal value. Severe metabolic acidosis is associated with worse clinical outcomes and development of organic dysfunctions (MACIEL et al., 2010)
None of the dogs in this study received sodium bicarbonate for correcting acidosis, suggesting that fluid therapy and a decrease in bicarbonate loss by effective treatment were sufficient for correcting this disorder. The results demonstrated that an increase of $1 \mathrm{mmol} \mathrm{L}^{-1}$ in bicarbonate reduced the risk of death by $43 \%$.

TheBEvalue athospital admission correlates with survival and serves as an indicator of hypoperfusion in trauma patients (KAPLAN; FRANGOS, 2004). A study analyzing arterial blood samples collected at admission to the intensive care unit and 24 hours later found that $\mathrm{BE}$ and lactate had good prognostic values. In addition, the value at admission with the best predictive capacity was lower than $-4 \mathrm{mmol}$ $\mathrm{L}^{-1}$; therefore, $\mathrm{BE}$ can be used to identify patients with a higher risk of death (SMITH et al., 2001). A veterinary study evaluated the predictive capacity of lactate and $\mathrm{BE}$ for clinical outcome and gastric necrosis in dogs with gastric dilatation-volvulus and concluded that BE could not be used to predict these parameters in this population (BEER et al., 2013). A retrospective study performed a multivariate regression analysis of data from the medical records of 566 dogs and 185 cats and found that BE was an independent predictor of mortality in dogs (KOHEN et al., 2018). A study involving dogs admitted to the intensive care unit following blunt trauma concluded that $\mathrm{BE}$ was a predictor of mortality and blood transfusion (STILLION; FLETCHER, 2012). For dogs with parvoviral enteritis, BE has an essential function as a prognostic factor, since the increase of $1 \mathrm{mmol} \mathrm{L}^{-1}$ in this variable reduces the risk of death by $38 \%$.

$\mathrm{PaO}_{2}$ is an important variable in critically ill patients. Pulmonary oxygenation impairment may be the first severe prognostic indicator of poor outcome in patients with sepsis and requires differential diagnosis because of possible consequences (HÜCKSTÄDT et al., 2016). In this study, the increase of $1 \mathrm{mmHg}$ in this parameter reduced the risk of death by $10 \%$. The same effect was expected in both $\mathrm{SO}_{2}$ and $\mathrm{PaO}_{2}$ because these 
two variables were correlated. A $1 \%$ increase in $\mathrm{SO}_{2}$ reduced the risk of death by $11 \%$.

The results indicate the importance of the search for normalization of parameters since there may be a direct effect on the survival of dogs with parvoviral enteritis. Blood gas analysis allowed identifying the highest number of prognostic factors. This analysis also allowed adjusting the animals' therapy by better choosing the replacement fluid to be used, performing the nutritional correction of metabolic acidosis, and making adjustments in serum electrolyte levels (ROCCO, 2003; HOPPER; HASKINS, 2008).

\section{Conclusions}

There is little information on the use of common variables such as clinical parameters and hematological data in dogs with parvovirus infections and sepsis. The objective of this study was to determine the potential effects of changes in clinical parameters on outcome and mortality. The results indicated that septic dogs with parvoviral enteritis and an increase in blood pressure, total leukocytes, lymphocytes and monocytes, partial pressure of oxygen, base deficit, and bicarbonate might have better clinical outcomes. However, increased heart rate was associated with a higher mortality rate. Additional prospective studies are needed to confirm the role of these prognostic factors.

\section{Conflicts of Interests}

None of the authors of this article has a financial or personal relationship with other individuals or organizations that could inappropriately influence or bias the content of the paper.

\section{References}

BASTAN, I.; KURTDEDE, A.; ÖZEN, D. Prognostic usefulness of some parameters in dogs with canine parvovirus. Ankara Üniversitesi Veteriner Fakultesi Dergisi, Ankara, v. 60, n. 1, p. 53-58, 2013. DOI: 10.1501/Vetfak_0000002880.

BEER, K. A. S.; SYRING, R. R. S.; DROBATZ, K. J. $\mathrm{K}$. Evaluation of plasma lactate concentration and base excess at the time of hospital admission as predictors of gastric necrosis and outcome and correlation between those variable in dogs with gastric dilatation-volvulus: 78 cases (2004-2009). Journal of the American Veterinary Medical Association, Schaumburg, v. 242, n. 1, p. 5458, 2013. DOI: 10.2460/javma.242.1.54. 10.2460/ javma.242.1.54.

DREWRY, A.; SAMRA, N.; SKRUPKY, L.; FULLER, B. M.; COMPTON, S. M.; HOTCHKISS, R. S. Persistent lymphopenia after diagnosis of sepsis predicts mortality. Shock, St. Louis, v. 42, n. 5, p. 383-391, 2014. DOI: 10.1097/SHK.0000000000000234.

GODDARD, A.; LEISEWITZ, A. L. Canine parvovirus. Veterinary Clinics of North America: Small Animal Practice, Pretória, v. 40, n. 6, p. 1041-1053, 2010. DOI: 10.1016/j.cvsm.2010.07.007.

GODDARD, A.; LEISEWITZ, A. L.; CHRISTOPHER, M. M.; DUNCAN, N. M.; BECKER, P. J. Prognostic usefulness of blood leukocyte changes in canine parvoviral enteritis. Journal of Veterinary Internal Medicine, Pretória, v. 22, n. 2, p. 309-316, 2008. DOI: 10.1111/j.1939-1676.2008.0073.x.

GREEN, T. I.; TONOZZI, C. C.; KIRBY, R.; RUDLOFF, E. Evaluation of initial plasma lactate values as a predictor of gastric necrosis and initial and subsequent plasma lactate values as a predictor of survival in dogs with gastric dilatation-volvulus: 84 dogs (2003-2007). Journal of Veterinary Emergency and Critical Care, Irving, v. 21, n. 1, p. 36-44, 2011. DOI: 10.1111/j.14764431.2010.00599.x .

HARDY, J. P.; STREETER, E. M.; DECOOK, R. R. Retrospective evaluation of plasma cholesterol concentration in septic dogs and its association with morbidity and mortality: 51 cases (2005-2015). Journal of Veterinary Emergency and Critical Care, Iowa City, v. 28 , n. 2, p. 149-156, 2018. DOI: $10.1111 /$ vec. 12705 .

HAUPTMAN, J. G.; WALSHAW, R.; OLIVIER, N. B. Evaluation of the sensitivity and specificity of diagnostic criteria for sepsis in dogs. Veterinary Surgery, East Lansing, v. 26, n. 5, p. 393-397, 1997. DOI: 10.1111/j.1532-950x.1997.tb01699.x.

HOLLENBERG, S. M. Inotrope and vasopressor therapy of septic shock. Critical Care Nursing Clinics of North America, Dorrance, v. 23, n. 1, p. 127-148, 2011. DOI: 10.1016/j.ccc.2009.07.003. 
HOPPER, K.; HASKINS, S. C. A case-based review of a simplified quantitative approach to acid-base analysis. Journal of Veterinary Emergency and Critical Care, Davis, v. 18, n. 5, p. 467-476, 2008. DOI: 10.1111/j.14764431.2008.00344.x.

HÜCKSTÄDT, M.; HOFMANN, G.; MENDEL, T.; STUTTMANN, R.; HILBERT-CARIUS, P. Die veränderung der oxygenierung chirurgischer intensivpatienten. Der Anaesthesist, Halle, v. 65, n. 11, p. 832-840, 2016. DOI: 10.1007/s00101-016-0224-x.

KALLI, I.; LEONTIDES, L. S.; MYLONAKIS, M. E.; ADAMAMA-MORAITOU, K.; RALLIS, T.; KOUTINAS, A. F. Factors affecting the occurrence, duration of hospitalization and final outcome in canine parvovirus infection. Research in Veterinary Science, Salonica, v. 89, n. 2, p. 174-178, 2010. DOI: 10.1016/j. rvsc.2010.02.013.

KAPLAN, L.; FRANGOS, S. Clinical review: acid-base abnormalities in the intensive care unit. Critical Care, New Haven, v. 9, n. 2, p. 198-203, 2004. DOI: 10.1186/ cc2912.

KOHEN, C. J.; HOPPER, K.; KASS, P. H.; EPSTEIN, S. E. Retrospective evaluation of the prognostic utility of plasma lactate concentration, base deficit, $\mathrm{pH}$, and anion gap in canine and feline emergency patients. Journal of Veterinary Emergency and Critical Care, Davis, v. 28, n. 1, p. 54-61, 2018. DOI: 10.1111/vec.12676.

LAMM, C. G.; REZABEK, G. B. Parvovirus infection in domestic companion animals. Veterinary Clinics of North America: Small Animal Practice, Stillwater, v. 38, n. 4, p. 837-850, 2008. DOI: 10.1016/j.cvsm.2008.03.008.

LETENDRE, J.; GOGGS, R. Determining prognosis in canine sepsis by bedside measurement of cell-free DNA and nucleosomes. Journal of Veterinary Emergency and Critical Care, Ithaca, v. 28, n. 6, p. 1-9, 2018. DOI: 10.1111/vec. 12773 .

LEVY, M. M.; FINK, M. P.; MARSHALL, J. C.; ABRAHAM, E.; ANGUS, D.; COOK, D.; COHEN, J.; OPAL, S. M.; VINCENT, J. L., RAMSAY, G. $2001 \mathrm{SCCM} / \mathrm{ESICM} / \mathrm{ACCP} / \mathrm{ATS} / \mathrm{SIS}$ international sepsis definition conference. Intesive Care Medicine, Providence, v. 31 , n. 4, p. 1250-1256, 2003. DOI: 10.1007/s00134-003-1662-x.

MACIEL, A. T.; NORITOMI, D. T.; PARK, M. Metabolic acidosis in sepsis. Endocrine, Metabolic \& Immune Disorders Drug Targets, São Paulo, v. 10, n. 3, p. 252-257, 2010. DOI: 10.2174/187153010791936900.

MIRANDA, C.; CARVALHEIRA, J.; PARRISH, C. R.; THOMPSON, G. Factors affecting the occurrence of canine parvovirus in dogs. Veterinary Microbiology,
Porto, v. 180, n. 1-2, p. 59-64, 2015. DOI: 10.1016/j. vetmic.2015.08.002.

MORTIER, F.; STROHMEYER, K.; HARTMANN, K.; UNTERER, S. Acute haemorrhagic diarrhoea syndrome in dogs: 108 cases. Veterinary Record, Munich, v. 176, n. 24, p. 629-631, 2015. DOI: 10.1136/vr.103090.

OSTERBUR, K.; MANN, F.; KUROKI, K.; DECLUE, A. Multiple organ dysfunction syndrome in humans and animals. Journal of Veterinary Internal Medicine, Pittsburgh, v. 28, n. 4, p. 1141-1151, 2014. DOI: 10.1111/ jvim.12364.

OTTO, C.; DROBATZ, K.; SOTER, C. Endotoxemia and tumor necrosis factor activity in dogs with naturally occurring parvoviral enteritis. Journal of Veterinary Internal Medicine, Philadelphia, v. 11, n. 2, p. 65-70, 1997. DOI: 10.1111/j.1939-1676.1997.tb00075.x.

PANDYA, S. M.; SHARMA, K. K.; KALYANI, I. H.; SAKHARE, P. S. Study on host predisposing factors and diagnostic tests for canine parvovirus (CPV-2) infection in dogs. Journal of Animal Research, Gujarat, v. 7, n. 5, p. 897-902, 2017. DOI: 10.5958/2277-940X.2017.00137.1.

PRITTIE, J. Canine parvoviral enteritis: a review os diagnosis, management, and prevention. Journal of Veterinary Emergency and Critical Care, New York, v. 14 , n. 3 , p. $167-179,2004$. DOI: 10.1111/j.15346935.2004.04020.x.

PRITTIE, J. Optimal endpoints of resuscitation and early goal-directed therapy. Journal of Veterinary Emergency and Critical Care, New York, v. 16, n. 4, p. 329-339, 2006. DOI: 10.1111/j.1476-4431.2006.00186.x.

RASKIN, R.; LATIMER, K.; TVEDTEN, H. Leukocytes disorders. In: WILLARD, M.; TVEDTEN, H. (Ed.). Small animal clinical diagnosis by laboratory methods. $4^{\text {th }}$ ed. St Louis: Elsevier, 2004. p. 63-91.

ROCCO, J. Diagnóstico dos distúrbios do metabolismo ácido-base. Revista Brasileira Terapia Intensiva, Rio de Janeiro, v. 15, n. 4, p. 184-192, 2003. DOI: 10.1590/ s0103-507x2006000400010.

ROSENSTEIN, P.; TENNENT-BROWN, B.; HUGHES, D. Clinical use of plasma lactate concentration. Part 2: prognostic and diagnostic utility and the clinical management of hyperlactatemia. Journal of Veterinary Emergency and Critical Care, Victoria, v. 28, n. 2, p. 106-121, 2018. DOI: 10.1111/vec.12706.

SCHMITZ, S.; COENEN, C.; KÖNIG, M.; THIEL, H.; NEIGER, R. Comparison of three parid commercial canine parvovirus antigen detection tests with electron microscopy and polymerase chain reaction. Journal of Veterinary Diagnostic Investigation, König, v. 21, n. 3, p. 344-345, 2009. DOI: 10.1177/104063870902100306. 
SHARKEY, L. C.; WELLMAN, M. L. Use of lactate in small animal clinical practice. Veterinary Clinics of North America: Small Animal Practice, Ohio, v. 43, n. 6, p. 1287-1297, 2013. DOI: 10.1016/j.cvsm.2013.07.012.

SHARP, C. L. systemic inflammatory response syndrome, sepsis, and multiple organ dysfunction syndrome. In: DROBATZ, K. J.; HOPPER, K.; ROZANSKI, E.; SILVERSTEIN, D. C. (Ed.). Textbook of small animal emergency medicine. Hoboken: Wiley Blackwell, 2019. p. 1030-1037.

SILVEIRA, M. M.; CÂNDIDO, S. L.; SANTOS, K. R.; MAIA, A. O.; SOUZA, R. L.; SOUSA, V. R. F.; ALMEIDA, A. B. P. F.; DUTRA, V.; NAKAZATO, L. Polymerase chain reaction and blood culture for diagnosis of canine sepsis. Ciência Rural, Santa Maria, v. 48, n. 6, p. 1-4, 2018. DOI: 10.1590/0103-8478cr20170871.

SINGER, M.; DEUTSCHMAN, C. S.; SEYMOUR, C. W.; SHANKAR-HARI, M.; ANNANE, D.; BAUER, M.; BELLOMO, R.; BERNARD, G. R.; CHICHE, J. D.; COOPERSMITH, C. M.; HOTCHKISS, R. S.; LEVY, M. M.; MARSHALL, J. C.; MARTIN, G. S.; OPAL, S. M.; RUBENFELD, G. D.; POLL, T. V. D.; VINCENT, J. L.; ANGUS, D. C. The third international consensus definitions for sepsis and septic shock (Sepsis-3). Journal of the American Medical Association, New York, v. 315, n. 8 , p. $801-810,2016$. DOI: $10.1001 /$ jama.2016.0287
SMITH, I.; KUMAR, P.; MOLLOY, S.; RHODES, A.; NEWMAN, P. J.; GROUNDS, R. M.; BENNET, E. D. Base excess and lactate as prognostic indicators for patients admitted to intensive care. Intesive Care Medicine, London, v. 27, n. 1, p. 74-83, 2001. DOI: $10.1007 / \mathrm{s} 001340051352$.

STEVENSON, C.; KIDNEY, B.; SNEAD, E.; MAINARJAIME, R.; JACKSON, M. Serial blood lactate concentrations in systemically ill dogs. Vetrinary Clinical Pathology, Zaragoza, v. 36, n. 3, p. 234-239, 2007. DOI: 10.1111/j.1939-165x.2007.tb00217.x.

STILLION, J. R.; FLETCHER, D. J. Admission base excess as a predictor of transfusion requirement and mortality in dogs with blunt trauma: 52 cases (20072009). Journal of Veterinary Emergency and Critical Care, New York, v. 22, n. 5, p. 588-594, 2012. DOI: 10.1111/j.1476-4431.2012.00798.x.

VINCENT, J.; BACKER, D. Circulatory shock. The New Englanda Journal of Medicine, Brussels, v. 369, n. 18, p. 369-387, 2013. DOI: 10.1056/NEJMra1208943.

WALTERS, A. M.; O'BRIEN, M. A.; SELMIC, L. E.; MCMICHAEL, M. A. Comparison of clinical findings between dogs with suspected anaphylaxis and dogs with confirmed sepsis. Journal of the American Veterinary Medical Association, Illinois, v. 251, n. 6, p. 681-688, 2017. DOI: $10.2460 /$ javma.251.6.681. 
